\title{
KEEFEKTIFAN MODEL PEMBELAJARAN STUDENT FACILITATOR AND EXPLAINING BERBANTU MEDIA TIMELINE CHART TERHADAP HASIL BELAJAR IPS
}

\author{
Mehziy Antikha $\mathrm{Ayu}^{1}$, Rahmat Sudrajat ${ }^{2}$, Arfilia Wijayanti ${ }^{3}$ \\ Jurusan Pendidikan Guru Sekolah Dasar, Fakultas IImu Pendidikan \\ Universitas PGRI Semarang \\ email : antikhamehziy@gmail.com ${ }^{1}, \underline{\text { rahmatsudarjat45@gmail.com }}^{2}$, arfilia46@gmail.com $^{3}$
}

\begin{abstract}
Abstrak
Latar belakang yang mendorong penelitian ini adalah rendahnya hasil belajar siswa terhadap pelajaran IPS, banyak siswa yang sulit menghafal dan memahami banyak materi IPS yang dirasa banyak teori yang menuntut siswa untuk mengerti semua yang ada dalam buku pelajaran. Penelitian ini bertujuan untuk mengetahui keefektifan model pembelajaran pembelajaran student facilitator and explaining berbantu media timeline chart terhadap hasil belajar IPS siswa kelas V SD Negeri 01 kebojongan. Jenis penelitian ini adalah kuantitatif dengan desain penelitian pre eksperimental design dan jenis yang diambil adalah one group pretest posttest design. Sampel yang diambil adalah 28 siswa kelas $\mathrm{V}$ dengan menggunakan teknik non probability sampling dengan menggunakan sampling jenuh. Penelitian diperoleh rata-rata pretest adalah 47,67, sedangkan posttest sebesar 79,82. Dengan menggunakan uji $t$, diperoleh $t$ hitung $>t$ tabel yaitu 12,66>2,052 maka $\mathrm{H} 0$ ditolak dan Ha diterima. Pada nilai afektif siswa setelah melakukan penelitian ada 5 siswa yang memperoleh kriteria baik sekali dan 23 siswa memperoleh kriteria baik, dengan rata-rata akhir 88,19. Pada aspek psikomotorik dan semua siswa mendapat predikat baik, dengan rata-rata akhir 82,73 . Terdapat perbedaan nilai hasil pretest dan posttest serta peningkatan hasil belajar (kognitif, afektif, psikomotorik) IPS siswa kelas V SDN 01 Kebojongan sehingga dapat disimpulkan bahwa ada keefektifan pada proses pembelajaran menggunakan model Student Facilitator and Explaining berbantu media Timeline Chart terhadap hasil belajar IPS siswa kelas V SDN 01 Kebojongan.
\end{abstract}

Kata kunci: keefektifan, student facilitator and explaining, timeline chart, IPS

\begin{abstract}
The background that drives this research was the low student learning outcomes for social studies, many students were difficult to memorize and understand a lot of social studies material which felt by many theories that require students to understand everything in the textbook. This study aimed to determine the effectiveness of the student facilitator and explaining learning model assisted by media timeline charts on social studies learning outcomes of fifth grade students of 01 elementary school kebojongan. This type of research was quantitative with pre experimental design research and one group pretest posttest design. The samples were 28 fifth grade students by probability sampling techniques using saturated sampling. The research obtained an average pretest score was 47.67 , while the posttest score was 79.82. By using the t test, it obtained t count> $t$ table that 12.66>2.052 then $\mathrm{HO}$ rejected and $\mathrm{Ha}$ accepted. On the affective value of students after conducting research there were 5 students who received excellent criteria and 23 students obtained good criteria, with a final average of 88.19. In the psychomotor aspects and all students received good titles, with the final average 82.73. There are differences in the value of the results of the pretest and posttest as well as the improvement in learning outcomes (cognitive, affective, psychomotor) Social Sciences of fifth grade students at SDN 01 Kebojongan so that it can be concluded that there is effectiveness in the learning process using Student Facilitator models and Explaining media-assisted Timeline Chart V SDN 01 Kebojongan.
\end{abstract}

Keywords: effectiveness, student facilitator and explaining, timeline chart, IPS 


\section{Pendahuluan}

Menurut Undang-Undang Sistem Pendidikan Nasional No.20 Tahun 2003 pasal 1 butir 1, pendidikan adalah: "usaha sadar dan terencana untuk mewujudkan suasana belajar dan proses pembelajaran agar peserta didik secara aktif mengembangkan potensi dirinya untuk memiliki kekuatan spiritual keagamaan, pengendalian diri, kepribadian, kecerdasaan, akhlak mulia, serta keterampilan yang diperlukan dirinya, masyarakat, bangsa dan Negara." Pendidikan nasional bertujuan: "untuk mengembangkan potensi peserta didik agar menjadi manusia yang beriman dan bertakwa kepada Tuhan Yang Maha Esa, berakhlak mulia, cakap, kreatif, mandiri, dan menjadi waarga Negara yang demokratis serta bertanggung jawab" (UU Sisdiknas No. 20 tahun 2003 pasal 3) (Ayu, 2017).

Pendidikan adalah proses memanusiakan manusia menjadi pribadi yang lebih baik, proses mendewasakan manusia menjadi individu yang lebih kritis dalam menyikapi suatu persoalan dan membuat seseorang yang tadinya tidak tahu menjadi tahu, yang tadinya mungkin tidak bisa atau belum bisa menjadi bisa. Menurut Undang-Undang Republik Indonesia No. 20 Tahun 2003 tentang Sistem Pendidikan Nasional (SISDIKNAS) pasal 1 ayat 1 menyebutkan bahwa pendidikan: Usaha sadar dan terencana untuk mewujudkan suasana belajar dan proses pembelajaran agar peserta didik secara aktif mengembangkan potensi dirinya untuk memiliki kekuatan spiritual, pengendalian diri, kepribadian, kecerdasan, akhlak mulia serta keterampilan yang diperlukan dirinya, masyarakat, bangsa, dan negara.

Pendidikan adalah hal terpenting bagi setiap negara untuk dapat berkembang pesat. Negara yang hebat akan menempatkan pendidikan sebagai prioritas pertamanya, karena dengan pendidikan, kemiskinan pada rakyat di negara tersebut akan dapat tergantikan menjadi kesejahteraan. Bagaimanapun, dalam perkembangannya, pendidikan di Indonesia senantiasa harus menghadapi beberapa masalah di setiap tahapnya. Masalahmasalah tersebut hanya dapat diselesaikan dengan partisipasi dari semua pihak yang terkait di dalam sistem pendidikan, seperti orangtua, guru-guru, kepala sekolah, masyarakat, dan juga peserta didik itu sendiri. Pada fase input, orangtua memiliki kontribusi besar dalam memperkenalkan nilai-nilai baik kepada anak-anak mereka. Orangtua bertanggung jawab penuh untuk mendidik anakanak mereka dengan nilai-nilai kepemimpinan, sehingga mereka mempunyai bekal yang cukup untuk menjadi cikal bakal pemimpin ketika mereka mulai memasuki institusi formal, seperti sekolah. Pada fase proses, orangtua bekerjasama dengan para guru dan kepala sekolah untuk memberikan penguatan kepada peserta didik dalam menerapkan nilai-nilai kepempinan yang baik melalui budaya organisasi di sekolah. Terakhir, pada tahap output, peserta didik harus menghadapi begitu banyak tantangan di dunia nyata, di luar sekolah. Peserta didik yang sudah melalui tahap-tahap sebelumnya di sekolah dengan budaya organisasi yang mengajarkan dan membiasakan nilai-nilai baik dalam hidupnya, maka akan tumbuh menjadi pemimpin yang hebat untuk negara ini (Megawanti, 2012).

Menurut Permendiknas No. 22 tahun 2006 menyebutkan bahwa IImu Pengetahuan Sosial (IPS):Salah satu mata pelajaran yang diberikan mulai dari SD/MI/SDLB sampai SMP/MTs/SMPLB. IPS mengkaji seperangkat peristiwa, fakta, konsep, dan generalisasi yang berkaitan dengan isu sosial. Pada jenjang SD/MI mata pelajaran IPS, peserta didik diarahkan untuk dapat menjadi warga Negara Indonesia yang demokratis, dan bertanggung jawab, serta warga dunia yang cinta damai. Berdasarkan Standar Kompetensi dan Kompetensi Dasar Tingkat SD/MI dalam Peraturan Menteri Pendidikan Nasional Nomor 22 tahun 2006 tentang standar isi untuk satuan pendidikan dasar dan menengah bahwa Standar Kompetensi (SK) dan Kompetensi Dasar (KD) Ilmu Pengetahuan Sosial merupakan salah satu mata pelajaran yang diberikanmulai dari SD/MI/SDLB sampai SMP/MTs/SMPLB. IPS mengkaji seperangkat peristiwa, fakta, konsep, dan generalisasi yang berkaitan dengan isu sosial. Pada jenjang SD/MI mata pelajaran IPS memuat materi geografi, sejarah, sosiologi, dan ekonomi. Mata pelajaran IPS disusun secara sistematis, komprehensif, dan terpadu dalam proses pembelajaran yang menuju kedewasaan dan keberhasilan dalam kehidupan di masyarakat. 
Dengan mempelajari IPS diharapkan peserta didik akan memperoleh pemahaman yang lebih luas dan mendalam pada bidang ilmu yang berkaitan.

Menurut Permana (2017: 1), "IPS merupakan bagian dari kurikulum sekolah yang tanggung jawab utamanya adalah membantu siswa dalam mengembangkan pengetahuan, keterampilan dan nilai yang diperlukan untuk berpartisipasi dalam kehidupan masyarakat baik ditingkat lokal, nasional maupun global". Menurut Sadirman dalam Permana (2017: 2), ilmu pengetahuan sosial juga membahas hubungan antar manusia dengan lingkungannya. Lingkungan masyarakat dimana anak didik tumbuh dan berkembang sebagian bagian dari masyarakat, dihadapkan pada berbagai permasalahan yang ada terjadi di lingkungan sekitarnya. Pendidikan IPS berusaha membantu siswa dalam memecahkan permasalahan yang dihadapi sehingga akan menjadikannya semakin mengerti dan memahami lingkungan sosial masyarakat.

Berdasarkan hasil observasi peneliti kelapangan di SD Negeri 01 Kebojongan, banyak siswa yang sulit menghafal dan memahami banyak materi IPS yang dirasa banyak teori yang menuntut siswa untuk mengerti semua yang ada dalam buku pelajaran apalagi mata pelajaran IPS yang biasanya mempunyai materi lebih banyak dibanding dengan mata pelajaran yang lain khususnya materi IPS tentang sejarah. Hal ini di ungkapkan oleh guru kelas V SDN 01 Kebojongan yang mana siswa kurang dalam memahami materi sehingga sulit menghafal materi IPS karena terlalu banyaknya materi IPS yang harus dipelajari. Tidak adanya model yang diterapkan dalam pembelajaran, hanya menggunakan metode ceramah dan diskusi saja dan tidak adanya media yang diterapkan juga membuat siswa kurang antusias dalam pembelajaran sehingga hasil belajar IPS siswa menjadi rendah. KKM untuk mata pelajaran IPS adalah 70. Jumlah siswa di kelas V SD Negeri 01 Kebojongan Tahun 2018/2019 adalah 28 siswa. Yang mendapat nilai mata pelajaran IPS di bawah KKM adalah 64,28\% atau 18 siswa. Sedangkan yang di atas KKM adalah $35,72 \%$ atau 10 siswa. Berarti siswa yang mendapat nilai di bawah KKM lebih banyak dari siswa yang mendapat nilai di atas KKM.

Hasil belajar menjadi sangat penting karena dengan adanya hasil belajar, pendidik menjadi lebih mudah dalam menilai siswa, baik dari nilai kognitif, afektif maupun psikomoriknya. Seperti yang dijelaskan oleh Dimyati dan Mudjiono (2009: 3), "Hasil belajar merupakan dari suatu interaksi tindak belajar dan mengajar". Sedangkan menurut Sudjana (2014: 22), "Hasil belajar adalah kemampuan-kemampuan yang dimiliki siswa setelah ia menerima pengalaman belajarnya". Sedangkan menurut Horward Kingsley dalam Sudjana (2014: 22), "Ada tiga macam hasil belajar, yakni keterampilan dan kebiasaan, pengetahuan dan pengertian, sikap dan cita-cita".

Oleh karena itu peneliti tertarik untuk menggunakan model Student Facilitator and Explaining berbantu media Timeline Chart dalam mengatasi permasalahan yang terkait dengan permasalahan IPS di SDN 01 Kebojongan kelas V. Shoimin (2017: 183-185), mengatakan model pembelajaran Student Facilitator and Explaining merupakan salah satu tipe pembelajaran kooperatif yang menekankan pada struktur khusus yang dirancang untuk mempengaruhi pola interaksi peserta didik dan memiliki tujuan untuk meningkatkan penguasaan materi. Penerapan model pembelajaran harus bisa memperbanyak pengalaman serta meningkatkan motivasi belajar yang mempengaruhi keaktifan belajar peserta didik, yaitu dengan menggunakan model pembelajaran Student Facilitator and Explaining. Dengan menggunakan model pembelajaran ini dapat meningkatkan antusias, motivasi, keaktifan, dan rasa senang. Oleh sebab itu, sangat cocok dipilih guru untuk digunakan karena mendorong peserta didik menguasai beberapa keterampilan di antaranya berbicara, menyimak, dan pemahaman pada materi. Beberapa kelebihan model pembelajaran Student Facilitator and Explaining: 1) materi yang disampaikan lebih jelas dan konkret; 2) dapat meningkatkan daya serap siswa karena pembelajaran dilakukan dengan demonstrasi; 3) melatih siswa untuk menjadi guru karena siswa diberikan kesempatan untuk mengulangi penjelasan guru yang telah dia dengar; 4) memacu motivasi siswa untuk menjadi yang terbaik dalam menjelaskan materi ajar; 5) mengetahui kemampuan siswa dalam menyampaikan ide tau gagasan.

Menurut Hafsari, Dwi. dkk (2016: 2), dalam penelitiannya yang termuat di dalam jurnal berjudul "Penerapan Model Pembelajaran Kooperatif Tipe Student Facilitator and Explaining 
untuk Meningkatkan Hasil Belajar IPS Siswa Kelas IV SD Negeri 56 Pekanbaru". Berdasarkan hasil penelitian dan analisis data yang dilakukan oleh peneliti, dapat disimpulkan bahwa Penerapan model pembelajaran kooperatif tipe Student Facilitator and Explaining dapat meningkatkan aktivitas guru dan siswa, terbukti pada siklus I pertemuan pertama memperoleh persentase $75 \%$ (kategori baik), pertemuan kedua menjadi $79.17 \%$ (kategori baik). Siklus II pertemuan pertama persentase $83.33 \%$ (kategori sangat baik), pertemuan kedua menjadi 91.67\% (kategori sangat baik). Penerapan model pembelajaran kooperatif tipe Student Facilitator and Explaining dapat meningkatkan hasil belajar siswa.

Menurut peneliti model Student Facilitator and Explaining akan membantu siswa dalam berpikir kritis dalam proses pembelajaran karena model ini memacu siswa untuk aktif dan berani dalam mengungkapkan pendapatnya didepan siswa yang lain berdasarkan penjelasan yang telah disampaikan oleh guru. Peneliti juga menggunakan media pembelajaran untuk memudahkannya dalam menyampaikan materi kepada siswa. Peneliti menggunakan media Timeline Chart. Timeline Chart menurut Arsyad (2014: 131), yaitu garis (alur) waktu menggambarkan hubungan kronologis antara peristiwa-peristiwa yang terjadi. Chart seperti ini sering digunakan untuk menunjukkan kaitan waktu peristiwa-peristiwa bersejarah atau hubungan orang-orang terkenal dengan peristiwa-peristiwa itu. Gambar atau lukisan biasa pula menyertai peristiwa penting itu. Garis waktu amat bermanfaat unuk meringkaskan urutan waktu dari rangkaian peristiwa. Menurut peneliti media Timeline Chart ini dirasa akan membantu memudahkan peneliti dalam melakukan pengajaran didalam kelas, karena bagan garis waktu ini dapat memudahkan siswa dalam mengingat materi pelajaran berdasarkan kronologi waktunya, sehingga siswa dapat menghafal dan memahami materi dan bersemangat dalam proses pembelajaran karena pembelajaran berlangsung menyenangkan dan tidak membosankan.

Berdasarkan penelitian yang dilakukan oleh Epayanti. dkk (2015: 189), yang berjudul "Upaya Meningkatkan Pemahaman Konsep Pendidikan kewarganegaraan (PKn) dengan Media Charta Dikelas IV Sekolah Dasar". Berdasarkan hasil penelitian tentang penggunaan media charta dalam pembelajaran Pendidikan Kewarganegaraan di Kelas IV SDN 02 Menukung Kecamatan Menukung Kabupaten Melawi maka pada akhir penulisan skripsi ini dapat dirumuskan kesimpulan sebagai berikut: Kegiatan belajar mengajar menggunakan media charta meningkat persentase pelaksanaannya. Rata-rata skor tes yang diperoleh siswa pada pra siklus sebesar 55,45, siklus I sebesar 65,45 sedangkan pada siklus II sebesar 78,18 . Ini berarti dari siklus I ke siklus II hasil belajar siswa mengalami peningkatan. Dengan demikian dapat dikatakan bahwa penggunaan media charta berhasil meningkatkan pemahaman siswa terhadap pembelajaran Pendidikan Kewarganegaraan (PKn).

Berdasarkan latar belakang di atas, peneliti tertarik untuk mengambil judul dalam penelitian ini yaitu "Keefektifan Model Pembelajaran Student Facilitator and Explaining Berbantu Media Timeline Chart Terhadap Hasil Belajar IPS Siswa Kelas V SDN 01 Kebojongan".

\section{Metode}

Pada penelitian ini peneliti melaksanakan penelitian pada semester II tahun ajaran 2018/2019 pada bulan April 2019 yang bertempat di SD Negeri 01 Kebojongan Kecamatan Comal Kabupaten Pemalang. Dalam penelitian ini menggunakan design penelitian PreExperimental Design dengan jenis one grup pretest posttest design.

Dalam melakukan penelitian diperlukan suatu cara atau langkah-langkah dalam penelitian secara sistemastis. Berikut ini merupakan langkah-langkah yang dilakukan peneliti dalam melaksanakan penelitian ini yaitu: (1) merumuskan masalah penelitian, (2) menyusun hipotesis, (3) menyusun rancangan penelitian, (4) mengumpulkan data dengan cara melakukan tes awal 01, untuk mengukur skor rata-rata (mean) sebelum subjek mendapat pembelajaran dengan model Student Facilitator and Explaining, (5) memberikan perlakuan X, yaitu dengan pembelajaran menggunakan model Student Facilitator and Explaining, (6) melakukan tes akhir 02, untuk mengukur skor rata-rata setelah subjek mendapatkan perlakuan $X$, (7) 
membandingkan 01 dan 02 untuk menentukan ada atau tidaknya perbedaan sebagai akibat dari perlakuan $\mathrm{X}$.

Dalam hal ini perlakuan digunakan untuk mencari perbedaan pada hasil pretest dan posttest setelah diberi perlakuan melalui model pembelajaran Student Facilitator and Expalining berbantu media Timeline Chart dan peningkatan pada hasil belajar (kognitif, afektif, psikomotorik) IPS siswa kelas V SDN 01 Kebojongan setelah diberi perlakuan melalui model pembelajaran Student Facilitator and Expalining berbantu media Timeline Chart.Adapun teknik pengumpulan data yang digunakan dalam penelitian sebagai berikut:

Metode tes ini di akan dilakukan oleh peneliti untuk mengukur hasil belajar pada mata pelajaran IPS yaitu dengan adanya pretest dan posttest, pretest dilakukan sebelum adanya perlakuan model Student Facilitator and Explaining dan media Timeline Chart, sedangkan posttest dilakukan setelah adanya perlakuan menggunakan model Student Facilitator and Explaining berbantu media Timeline Chart.

Metode non tes yang digunakan oleh peneliti yaitu: Observasi yaitu dengan adanya pengamatan yang dilakukan oleh peneliti menggunakan alat indra untuk mengetahui proses kegiatan pembelajaran yang ada di SDN 01 Kebojongan.Dokumentasi digunakan untuk mendapatkan data nyata baik berupa foto atau dokumen daftar nama siswa dan juga video dalam proses penelitian di SDN 01 Kebojongan.Instrumen Penelitian yang digunakan yaitu validitas untuk mengetahui valid atau tidaknya soal uji coba ini, digunakan rumus sebagai berikut:

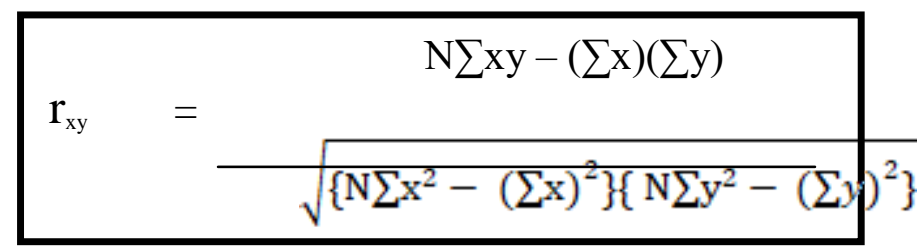

(Arikunto, 2010: 213

$\begin{array}{ll}r_{x y} & =\text { koefisien korelasi antara variabel }(\mathrm{X}) \text { dan variable }(\mathrm{Y}) \\ \mathrm{X} & =\text { skor soal } \\ \mathrm{Y} & =\text { skor total } \\ \mathrm{N} & =\text { banyaknya subyek yang uji coba } \\ \sum \mathrm{x} & =\text { jumlah seluruh skor untuk tiap butir soal } \\ \sum \mathrm{y} & =\text { jumlah skor soal } \\ \sum \mathrm{xy} & =\text { umlah perkalian skor item }(\mathrm{X}) \text { dan skor total }(\mathrm{Y})\end{array}$

Setelah didapat harga $r_{x y}$ kemudian dikonsultasikan dengan harga titik yang ada pada tabel dengan taraf nyata $5 \%$. Apabila $r_{x y}$ lebih besar dari harga tabel, maka butir soal tersebut dinyatakan valid. Namun, apabila $r_{x y}$ lebih kecil dari harga tabel, maka butir soal tersebut dinyatakan tidak valid, Perhitungan validitas dihitung dengan rumus product moment, setelah $r_{x y}$ didapatkan kemudian dikonsultasikan dengan $r_{\text {tabel }}$ yang didapat harga kritis $r_{\text {tabel }}$ product moment dengan $\mathrm{N}$ untuk signifikan $5 \%$ diperoleh $r_{\text {tabel. }}$. Apabila $r_{x y}$ lebih besar dari $r_{\text {tabel}}$, maka butir soal dinyatakan valid.

Reliabilitas untuk menguji reliabilitas instrumen tes digunakan akan digunakan rumus yang dikemukakan oleh Kuder dan Richardson yang dihitung dengan menggunakan rumus K-R 20, yaitu:

$$
r 11=\left(\frac{n}{n-1}\right)\left(\frac{s^{2}-\sum p q}{s^{2}}\right)
$$


dengan

$$
s^{2}=\frac{\sum y^{2}-\frac{\sum y^{2}}{N}}{N}
$$

Keterangan:

$\begin{array}{ll}r_{11} & =\text { Reliabilitas secara keseluruhan } \\ p & =\text { Proporsi subyek yang menjawab item dengan benar } \\ q & =\text { Proporsi subyek yang menjawab item dengan salah }(\mathrm{q}=1-\mathrm{p}) \\ \sum_{\mathrm{S}} p q & =\text { Jumlah hasil perkalian antara } \mathrm{p} \text { dan } \mathrm{q} \\ \mathrm{n} & =\text { Standar deviasi/varians } \\ & =\text { Banyaknya subjek pengikut tes }\end{array}$

klasifikasi reliabilitas:

Jika $0,00<r_{11} \leq 0,20=$ Reliabilitas sangat rendah

Jika $0,21<r_{11} \leq 0,40 \quad=$ Reliabilitas rendah

Jika $0,41<r_{11} \leq 0,71 \quad=$ Reliabilitas sedang

Jika $0,71<r_{11} \leq 0,90 \quad=$ Reliabilitas tinggi

Jika $0,91<r_{11} \leq 1,00=$ Reliabilitas sangat tinggi

Taraf $\alpha=5 \%$ apabila $r_{\text {hitung }}>r_{\text {tabel }}$ maka soal tes dikatakan reliabel. Apabila harga $r_{\text {hitung }}<$ $r_{\text {tabel }}$ maka instrumen tersebut dikatakan tidak reliabel.

Daya beda suatu soal dianggap baik apabila siswa yang pandai dapat menjawab dengan benar sehingga dengan semakin besar daya pembeda soal, maka soal tersebut semakin baik, digunakan rumus:

$$
D=\frac{B_{A}}{J_{A}}-\frac{B_{B}}{J_{B}}=P_{A}-P_{B}
$$

Keterangan:

$\mathrm{D} \quad=$ daya pembeda

$\mathrm{J} \quad=$ jumlah peserta tes

$\mathrm{JA} \quad=$ banyaknya peserta kelompok atas

$\mathrm{JB} \quad=$ banyaknya peserta kelompok bawah

$\mathrm{BA} \quad=$ banyaknya peserta kelompok atas yang menjawab benar

$\mathrm{BB} \quad=$ banyaknya peserta kelompok bawah yang menjawab benar

$\mathrm{PA}=$ proporsi peserta kelompok atas yang menjawab benar

$\mathrm{PB} \quad=$ proporsi peserta kelompok bawah yang

menjawab benar

(Arikunto, 2010: 228)

Klasifikasi daya pembeda:

$\mathrm{D} \quad=0,00-0,20$ : jelek

D $\quad=0,21-0,40:$ cukup

$\mathrm{D} \quad=0,41-0,70$ : baik

$\mathrm{D} \quad=0,71-1,00$ : baik sekali

Soal dikatakan valid $r_{\text {hitung }}>r_{\text {tabel. }}$ Setelah diperoleh harga $r_{x y}$ dari perhitungan kemudian dibandingkan dengan harga $r_{\text {tabel. }}$. Apabila harga $r_{x y}$ lebih besar dari $r_{\text {tabel }}$, akan dikatakan bahwa perangkat tes tersebut valid. Dengan reliabilitas harga $r_{x y}$ dibandingkan $r_{\text {tabel }}$ Product Moment. Apabila $r_{\text {hitung }}>r_{\text {tabel }}$ maka soal reliabel atau dapat dipercaya.

Bila soal itu baik maka soal tersebut dapat dikerjakan oleh siswa yang mampu dan siswa yang kurang tidak dapat mengerjakannya. Tetapi bila soal itu dapat dijawab oleh siswa yang 
mampu dan yang kurang maka soal tersebut tidak baik karena tidak mempunyai daya pembeda. Demikian juga soal yang dapat dijawab oleh siswa yang mampu atau siswa yang kurang, maka soal tersebut tidak baik karena tidak memiliki daya pembeda.

Tingkat kesukaran instrumen untuk menentukan tingkat kesulitan rumus sebagai berikut:

$$
P=\frac{B}{J S}
$$

Keterangan:

$\mathrm{P}=$ Indeks kesukaran

$\mathrm{B}=$ Banyaknya siswa yang menjawab soal itu dengan betul

$\mathrm{JS}=$ Jumlah seluruh peserta tes

(Arikunto, 2010: 223)

berikut:

Menurut ketentuan yang sering diikuti, indeks kesukaran sering diklasifikasikan sebagai

Soal dengan $P$ 0,00 sampai 0,30 adalah soal sukar

Soal dengan $P$ 0,31 sampai 0,70 adalah soal sedang

Soal dengan $P$ 0,71 sampai 1,00 adalah soal mudah

Teknik Analisis Data

Uji Normalitas

Adapun langkah-langkah yaitu:

Pengamatan $x 1, x 2, \ldots, x n$ dijadikan bilangan baku $z 1, z 2, \ldots, z n$ dengan menggunakan zi $\frac{x i-\bar{x}}{s}$ ( $\bar{x}$ dan s masing-masing merupakan rata-rata simpangan baku dan simpangan sampel)

Untuk tiap bilangan baku ini menggunakan daftar distribusi normal baku, kemudian dihitung peluang $\mathrm{F}(z i)=\mathrm{P}((z \leq z i)$.

Selanjutnya dihitung proporsi $z_{i}, z_{2} \ldots, z_{n}$ yang lebih kecil atau sama dengan $z_{i}$. jika

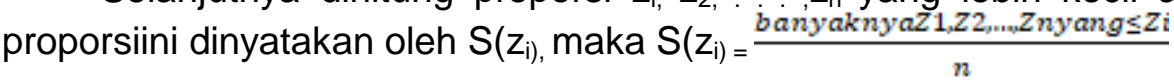

Hitung selisih $F\left(z_{i}\right)-S\left(z_{i}\right)$ kemudian tentukan harga mutlak.Ambilah harga yang paling besar diantara harga-harga mutlak selisih tersebut. Sebutlah harga tersebut $L_{o}$.

Membandingkan $L_{o}$ dengan $L_{\text {tabel }}$ pada taraf signifikan 0.05 dengan kriteria populasi berdistribusi normal jika $L_{o}<L_{\text {tabel. }}$.

Uji Hipotesis

Sesuai dengan data yang didapat oleh peneliti, maka selanjutnya akan dianalisis dengan uji-t. uji ini dilakukan untuk mengetahui dan memeriksa efektifitas perlakuan.

Rumus yang digunakan yaitu:

$$
t=\frac{M d}{\sqrt{\frac{\sum x^{2} d}{N(N-1)}}}
$$

(Arikunto, 2016: 125)

Keterangan:

$\mathrm{t}=$ harga $\mathrm{t}$

Md = mean dari deviasi (d) antara pretest dengan posttest

$\sum x^{2} d=$ jumlah kuadrat deviasi

$X \mathrm{~d}=$ deviasi masing-masing subjek ( $\mathrm{d}-\mathrm{Md}$ )

$\mathrm{N} \quad$ = banyaknya subjek pada sampel 


$$
\mathrm{Db}=\text { ditentukan dengan }(\mathrm{N}-1)
$$

Kriteria:

$\mathrm{H}_{0}$ diterima jika $\mathrm{t}_{\text {hitung }}<\mathrm{t}_{\text {tabel }}$

$\mathrm{H}_{0}$ ditolak jika $t_{\text {hitung }}>\mathrm{tt}_{\text {abel }}$

$\mathrm{T}_{\text {tabel }}$ diperoleh dengan derajat kebebasan untuk distribusi t ialah $(\mathrm{N}-1)$ dan taraf signifikan 0,05.

Uji ketuntasan hasil belajar

Ketuntasan hasil belajar individu Siswa dikatakan tuntas apabila nilai pretest atau posttest yang diperoleh lebih dari atau sama dengan nilai KKM.

$$
\mathrm{KBI}=\frac{\text { Fumlah skor yang diperoleh siswa }}{\text { jumlah skor max seluruhnya }} \mathrm{X} 100
$$

Ketuntasan hasil belajar klasikal (KBK) diukur dengan keberhasilan kelas dilihat dari jumlah peserta didik yang mampu menyelesaikan atau mencapai minimal $70 \%$, minimal sebanyak $85 \%$ dari jumlah peserta didik yang ada di kelas tersebut. Rumus yang digunakan untuk mengukur ketuntasan belajar kelas yaitu:

$$
\mathrm{KBK}=\frac{\text { fumlah siswa_ang tuntas belajar }}{\text { fumlah siswa yang mengikuti tes }} \boldsymbol{x} \mathbf{1 0 0} \%
$$

\section{Hasil Dan Pembahasan}

Penelitian ini dilakukan di kelas V SDN 01 Kebojongan pada semester genap Tahun Pelajaran 2018/2019, jenis pada penelitian ini adalah jenis penelitian kuantitatif dengan tujuan untuk mengetahui keefektifan model student facilitator and explaining berbantu media timeline chart untuk meningkatkan hasil belajar IPS siswa kelas V SDN 01 Kebojongan. Data penelitian diperoleh dari hasil belajar IPS, yaitu dari nilai pretest merupakan data awal yang diperoleh sebelum siswa diberi perlakuan dengan menggunakan model pembelajaran Student Facilitator and Explaining Berbantu Media Timeline Chart. Posttest merupakan data akhir yang diperoleh setelah siswa diberi perlakuan dengan menggunakan model pebelajaran Student Facilitator and Explaining Berbantu Media Timeline Chart.

Hasil belajar meliputi aspek kognitif, afektif dan psikomotorik. Aspek kognitif diperoleh melalui soal pretest dan posttest. Aspek afektif diperoleh dari pengamatan peneliti yaitu berpikir kritis, toleransi dan disiplin. Aspek psikomotorik diamati dari kemampuan mendemonstrasikan kronologi sejarah dari materi yang sudah diajarkan.

Sampel yang digunakan adalah sampel jenuh, dimana semua siswa kelas V SDN 01 Kebojongan diikut sertakan dalam penelitian ini, sebelum menentukan soal pretest dan posttest peneliti melakukan uji coba instrumen yang berjumlah 30 butir soal kemudian diujikan dengan uji validitas, reliabilitas, tingkat kesukaran dan daya pembeda. Dari uji instrumen tersebut peroleh soal yang valid berjumlah 22 soal dan 8 soal tidak valid, namun hanya 20 soal yang digunakan, kemudian 20 butir soal tersebut dipergunakan untuk pretest dan posttest, pada soal posttest dilakukan pengacakan soal dari soal pretest. Berdasarkan hasil analisis data nilai pretest dan posttest, nilai tertinggi pretest adalah 80 dan nilai terendah adalah 20, sedangkan rata-rata yang diperoleh adalah 47,67. Sedangkan nilai posttest nilai tertinggi adalah 100 dan nilai terendah adalah 50. Rata-rata nilai yang diperoleh dari posttest adalah 79,82. Persentase ketuntasan pretest adalah $25 \%$ sedangkan persentase ketuntasan posttest adalah $89,28 \%$. 


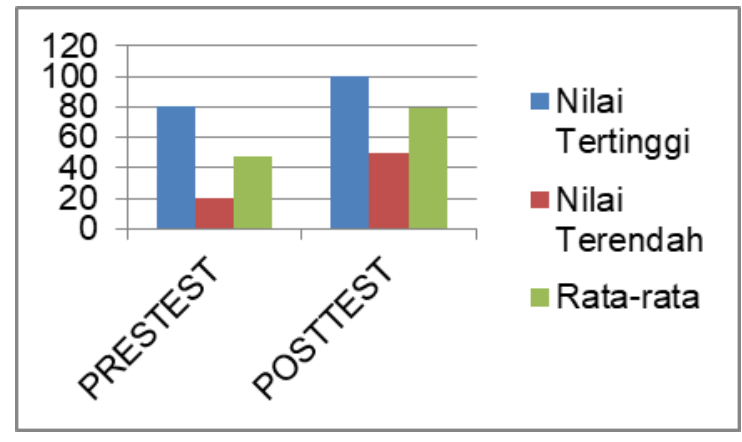

Gambar 1. Diagram nilai tertinggi, terendah dan rata-rata

Penelitian ini menggunakan teknik analisis data uji normalitas, uji hipotesis, dan hipotesis statistik.

Tabel 1. Uji Normalitas Awal

\begin{tabular}{lllll}
\hline Kelas & $\mathrm{N}$ & $\mathrm{L} 0$ & Ltabel & Kesimpulan \\
\hline Responden & 28 & 0,152 & 0,1641 & Berdistribusi normal \\
\hline & & & \multicolumn{2}{c}{ Sumber: Data Hasil Penelitian (2019) }
\end{tabular}

Pada uji normalitas awal dengan menggunakan data nilai pretest. Hasil pengujian normalitas data pretest diperoleh nilai Lhitung 0,152 dengan taraf signifikan $5 \% \mathrm{~N}=28$ maka diperoleh $L_{\text {tabel }} 0,1641$. Karena $L_{\text {hitung }}<L_{\text {tabel }}$ maka artinya data berdistribusi normal. Jadi data nilai pretest menunjukkan bahwa sampel berasal dari populasi berdistribusi normal.

Tabel 2. Uji Normalitas Akhir

\begin{tabular}{lrrrrr}
\hline Kelas & $\mathrm{N}$ & $\mathrm{LO}$ & & $\mathrm{L}_{\text {tabel }}$ & Kesimpulan \\
\hline & Responden & 28 & 0,1555 & 0,1641 & Berdistribusi normal \\
\hline & & & & \multicolumn{3}{c}{ Sumber: Data Hasil Penelitian (2019) }
\end{tabular}

Sedangkan hasil pengujian normalitas akhir dengan menggunakan data nilai posttest diperoleh nilai $L_{\text {hitung }} 0,1555$ dengan taraf signifikan $5 \% \mathrm{~N}=28$ maka diperoleh $L_{\text {tabel }} 0,1641$. Karena $L_{\text {hitung }}<L_{\text {tabel }}$ maka artinya data berdistribusi normal. Jadi data nilai posttest menunjukkan bahwa sampel berasal dari populasi berdistribusi normal.

Hasil pengujian hipotesis perhitungan uji $t$, diperoleh $t_{\text {hitung }}>t_{\text {tabel }}$ yaitu 12,66>2,052 maka $\mathrm{HO}$ ditolak $\mathrm{Ha}$ diterima. Jadi dapat disimpulkan bahwa ada perbedaan nilai rata-rata pretest dengan nilai rata-rata posttest pada hasil belajar IPS siswa kelas V SDN 01 Kebojongan. Sedangkan hasil perhitungan nilai posttest maka uji ketuntasan individu didapat ada 25 siswa yang nilainya mencapai KKM, dan 3 siswa yang nilainya dibawah KKM. Hasil perhitungan nilai posttest pada uji ketuntasan belajar klasikal diperoleh $89,28 \%$. Sehingga, ketuntasan belajar secara klasikal dinyatakan tuntas, karena persentase hasil belajar mencapai $>85 \%$.

Berdasarkan kriteria pengujian bahwa $\mathrm{HO}$ ditolak jika $t_{\text {hitung }}>\mathrm{t}_{\text {tabel }}$ yakni 12,66>2,052 dapat disimpulkan bahwa $\mathrm{H}_{0}$ ditolak dan $\mathrm{H}_{1}$ diterima yang berarti bahwa penggunaan model pembelajaran student facilitator and explaining berbantu media timeline chart efektif terhadap hasil belajar dan ketuntasan belajar siswa.

Selain ketuntasan nilai kognitif yakni berupa posttest, ketuntasan nilai siswa juga terlihat pada hasil penilaian afektif dan psikomotorik siswa. 


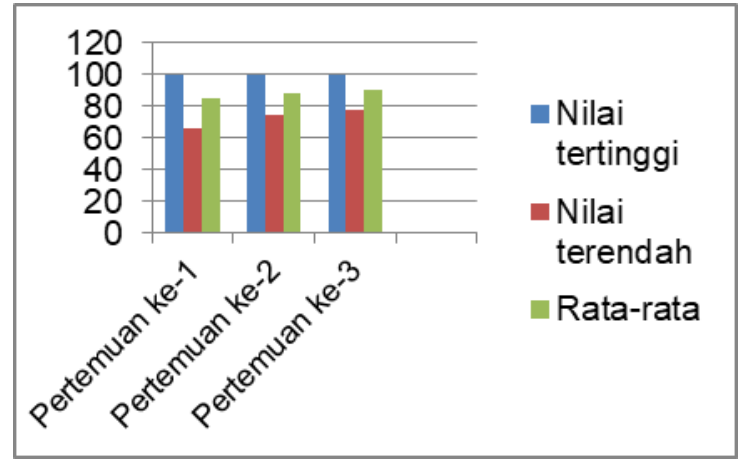

Gambar 2. Diagram Nilai Tertinggi, Terendah dan Rata-Rata Aspek Afektif

Berdasarkan tabel dan diagram diatas, nilai terendah aspek afektif pada pertemuan ke-1 adalah 66,66 dan nilai tertinggi aspek afektif pada pertemuan ke-1 adalah 100 . Nilai terendah aspek afektif pada pertemuan ke-2 adalah 75 dan nilai tertinggi aspek afektif pada pertemuan ke-2 adalah 100. Nilai terendah aspek afektif pada pertemuan ke-3 adalah 77,77 dan nilai tertinggi aspek afektif pada pertemuan ke-3 adalah 100. Untuk rata-rata dari setiap pertemuan mengalami peningkatan hasil belajar yaitu pada pertemuan ke-1 rata-rata yang diperoleh adalah 85,41 , pada pertemuan ke-2 rata-rata yang diperoleh adalah 88,19 dan pada pertemuan ke-3 rata-rata yang diperoleh adalah 90,86.

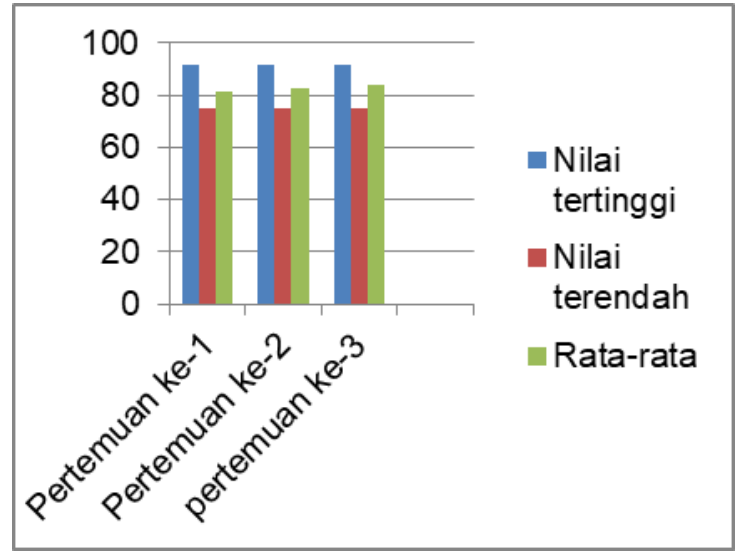

Gambar 3. Diagram Nilai Tertinggi, Terendah dan Rata-Rata Aspek Psikomotorik

Berdasarkan tabel diatas, nilai terendah aspek psikomotorik pada pertemuan ke-1 adalah 75 dan nilai tertinggi aspek psikomotorik pada pertemuan ke-1 adalah 91,66. Nilai terendah aspek psikomotorik pada pertemuan ke-2 adalah 75 dan nilai tertinggi aspek psikomotorik pada pertemuan ke-2 adalah 91,66. Nilai terendah aspek psikomotorik pada pertemuan ke-3 adalah 75 dan nilai tertinggi aspek psikomotorik pada pertemuan ke-3 adalah 91,66 . Untuk rata-rata dari setiap pertemuan mengalami peningkatan hasil belajar yaitu pada pertemuan ke-1 rata-rata yang diperoleh adalah 81,54, pada pertemuan ke-2 rata-rata yang diperoleh adalah 82,73 dan pada pertemuan ke-3 rata-rata yang diperoleh adalah 83,62.

Penerapan model student facilitator and explaining berbantu media timeline chart terhadap hasil belajar IPS kelas $\mathrm{V}$ di SDN 01 Kebojongan telah sesuai dengan langkahlangkah yang sudah dijelaskan pada kajian teori bahwa peran penting pada pembelajaran ini siswa sebagai fasilitator dituntut untuk kritis agar dapat menjelaskan atau mendemonstrasikan apa yang sudah dipelajari dalam pembelajaran tersebut. Shoimin (2017: 183-185), mengatakan model pembelajaran Student Facilitator and Explaining merupakan salah satu tipe pembelajaran kooperatif yang menekankan pada struktur khusus yang dirancang untuk mempengaruhi pola interaksi peserta didik dan memiliki tujuan untuk meningkatkan 
penguasaan materi. Penerapan model pembelajaran harus bisa memperbanyak pengalaman serta meningkatkan motivasi belajar yang mempengaruhi keaktifan belajar peserta didik, yaitu dengan menggunakan model pembelajaran Student Facilitator and Explaining. Dengan menggunakan model pembelajaran ini dapat meningkatkan antusias, motivasi, keaktifan, dan rasa senang. Oleh sebab itu, sangat cocok dipilih guru untuk digunakan karena mendorong peserta didik menguasai beberapa keterampilan di antaranya berbicara, menyimak, dan pemahaman pada materi. Beberapa kelebihan model pembelajaran Student Facilitator and Explaining: 1) materi yang disampaikan lebih jelas dan konkret; 2) dapat meningkatkan daya serap siswa karena pembelajaran dilakukan dengan demonstrasi; 3) melatih siswa untuk menjadi guru karena siswa diberikan kesempatan untuk mengulangi penjelasan guru yang telah dia dengar; 4) memacu motivasi siswa untuk menjadi yang terbaik dalam menjelaskan materi ajar; 5) mengetahui kemampuan siswa dalam menyampaikan ide tau gagasan.

Hasil penelitian ini sejalan dengan penelitian yang sudah dilakukan oleh Mulyani, Eva (2016) yang berjudul " Pengaruh penggunaan model pembelajaran kooperatif tipe Student facilitator and explaining terhadap pemahaman matematik peserta didik". Berdasarkan hasil uji statistika menggunakan uji perbedaan dua rata-rata diperolehan $t_{\text {hitung }}=4,17$ lebih dari terdaftar 2,38 , dengan taraf nyata $\alpha=1 \%$, artinya ada pengaruh positif penggunaan model pembelajaran kooperatif tipe student facilitator and explaining terhadap pemahaman matematik peserta didik.

Hasil belajar dengan menggunakan model student facilitator and explaining berbantu media timeline chart terhadap hasil belajar IPS kelas V di SDN 01 Kebojongan dikatakan efektif dikarenakan ada perbedaan pada hasil pretest dan posttest siswa setelah diberi perlakuan melalui model Student Facilitator And Explaining berbantu media Timeline Chart, dan ada peningkatan pada hasil belajar (kognitif, afektif, dan psikomotorik) IPS siswa kelas V SDN 01 Kebojongan setelah diberi perlakuan melalui model Student Facilitator And Explaining berbantu media Timeline Chart.

Hasil belajar siswa yang diajarkan menggunakan model student facilitator and explaining berbantu media timeline chart terhadap hasil belajar IPS kelas V di SDN 01 Kebojongan lebih baik dari sebelum menggunakan model student facilitator and explaining berbantu media timeline chart, sehingga model student facilitator and explaining efektif meningkatkan hasil belajar siswa dalam pembelajaran.

Pada pembelajaran ini guru menggunakan media timeline chart yang dirasa sangat cocok dengan model student facilitator and explaining karena dengan media timeline chart dapat memudahkan siswa sebagai perantara atau pengantar pesan yang ingin dipaparkan. Timeline Chart menurut Arsyad (2014: 131), yaitu garis (alur) waktu menggambarkan hubungan kronologis antara peristiwa-peristiwa yang terjadi. Chart seperti ini sering digunakan untuk menunjukkan kaitan waktu peristiwa-peristiwa bersejarah atau hubungan orang-orang terkenal dengan peristiwa-peristiwa itu. Gambar atau lukisan biasa pula menyertai peristiwa penting itu. Garis waktu amat bermanfaat unuk meringkaskan urutan waktu dari rangkaian peristiwa.

Hasil penelitian ini sejalan dengan penelitian yang sudah dilakukan oleh Epayanti. dkk (2015) yang berjudul "Upaya Meningkatkan Pemahaman Konsep Pendidikan Kewarganegaraan (PKn) Dengan Media Charta Di Kelas IV Sekolah Dasar". Berdasarkan hasil penelitian tentang penggunaan media charta dalam pembelajaran Pendidikan Kewarganegaraan di Kelas IV SDN 02 Menukung Kecamatan Menukung Kabupaten Melawi maka pada akhir penulisan skripsi ini dapat dirumuskan kesimpulan sebagai berikut: Kegiatan belajar mengajar menggunakan media charta meningkat persentase pelaksanaannya. Dengan demikian dapat dikatakan bahwa penggunaan media charta berhasil meningkatkan pemahaman siswa terhadap pembelajaran Pendidikan Kewarganegaraan (PKn).

\section{Simpulan dan Saran}

Berdasarkan hasil penelitian dan pembahasan hasil penelitian, maka peneliti membuat kesimpulan bahwa ada keefektifan menggunakan model Student Facilitator and Explaining berbantu media Timeline Chart terhadap hasil belajar IPS siswa kelas V SDN 01 Kebojongan . Hal ini dibuktikan dengan uji hipotesis dengan menggunakan uji $t$, diperoleh $t_{\text {hitung }}>t_{\text {tabel }}$ yaitu 
12,66> 2,052 maka $\mathrm{H} 0$ ditolak dan Ha diterima. $\mathrm{T}_{\text {tabel }}$ ditentukan dengan $\mathrm{db}=\mathrm{N}-1=27$ dan taraf $\alpha=0,05$ adalah 2,052. Jadi dapat disimpulkan bahwa ada keefektifan model Student Facilitator and Explaining berbantu media Timeline Chart terhadap hasil belajar IPS siswa kelas V SDN 01 Kebojongan, ada perbedaan pada hasil pretest dan posttest setelah diberi perlakuan melalui model Student Facilitator and Explaining berbantu media Timeline Chart, ada peningkatan pada hasil belajar (kognitif, afektif, dan psikomotorik) IPS siswa kelas V SDN 01 Kebojongan setelah diberi perlakuan melalui model Student Facilitator and Explaining berbantu media Timeline Chart.

Berdasarkan hasil penelitian yang sudah dilakukan, peneliti dapat memberikan saransaran sebagai berikut:

Bagi guru, model Student Facilitator and Explaining berbantu media Timeline Chart dapat meningkatkan hasil belajar siswa pada pelajaran IPS materi perjuangan pada masa penjajahan kelas $\mathrm{V}$ sehingga dapat menjadi variasi baru dalam kegiatan belajar mengajar di dalam kelas.

Bagi siswa, model Student Facilitator and Explaining berbantu media Timeline Chart dapat menjadi inovasi pembelajaran yang aktif, memberikan pengalaman baru bagi siswa, menjadi pembelajaran yang menyenangkan bagi siswa khususnya pada pelajaran IPS materi perjuangan pada masa penjajahan dan siswa dapat berpikir secara kritis tentang kronologi sejarah masa penjajahan pada media timeline chart. Selain itu model

Bagi sekolah, Pembelajaran menggunakan pembelajaran model Student Facilitator and Explaining berbantu media Timeline Chart dapat menjadi referensi bagi sekolah dalam rangka memperbaiki proses pembelajaran sehingga dapat meningkatkan hasil belajar siswa kelas $\mathrm{V}$ pada pelajaran IPS.

Keterbatasan Penelitian :

Berdasarkan hasil penelitian yang dilaksanakan dari tanggal 12 Januari 2018 s/d 15 Januari 2018, pada kelas V SDN 01 Kebojongan tahun ajaran 2018/2019, ada beberapa keterbatasan yang dialami oleh peneliti yaitu keterbatasan waktu yang tersedia dalam melakukan penelitian yang relatif singkat yaitu hanya selama tiga kali pertemuan, peneliti ini hanya terbatas pada kelas V SDN 01 Kebojongan, penelitian ini terbatas pada mata pelajaran IPS materi perjuangan pada masa penjajahan.

\section{Daftar Rujukan}

Arikunto, Suharsimi. 2010. Prosedur Penelitian: Suatu Pendekatan Praktik. Jakarta: Rineka Cipta.

Arikunto, Suharsimi. 2009. Manajemen Penelitian. Jakarta: Rineka Cipta.

Arsyad, Azhar. 2014. Media Pembelajaran. Jakarta: Rajawali Pers.

Ayu, Nanda. 2017. Pendidikan Karakter Sebagai Pilar Pembentukan Karakter Bangsa . Jurnal Fakultas Ilmu Sosial Universitas Negeri Medan Tahun 2017 Vol. 1 No. 1 2017, Hal. 348352

Dimyati dan Mudjiono. 2009. Belajar dan Pembelajaran. Jakarta: Rineka Cipta.

Epayanti, dkk.2015."Upaya Meningkatkan Pemahaman Konsep Pendidikan Kewarganegaraan (PKn) Dengan Media Charta Di Kelas IV Sekolah Dasar".Jurnal Pendidikan Dasar. (Volume3 No.(2),

Desember 2015).http://www.jurnalstkipmelawi.ac.id/index.php/JPD/article/download/87/163 Diakses pada 9 November 2018. 
Hafsari, Dwi dkk. 2016. Penerapan Model Pembelajaran Kooperatif Tipe Student Facilitator and Explaining untuk Meningkatkan Hasil Belajar IPSSiswa Kelas IV SD Negeri 56 Pekanbaru. Jurnal Online Mahasiswa Fakultas Keguruan dan IImu Pendidikan).(Vol. 3 No. 2).https://jom.unri.ac.id/index.php/JOMFKIP/article/view/12008. Diakses pada tanggal 14 Desember 2018.

Megawati, Priarti . 2012. Meretas Permasalahan Pendidikan Di Indonesia. Jurnal Formatif 2(3): 227-234 ISSN: 2088-351X

Mulyani, Eva. 2016. "Pengaruh penggunaan model pembelajaran kooperatif tipe student facilitator and explaining terhadap pemahaman matematik peserta didik" JP3M (Jurnal Penelitian Pendidikan dan Pengajaran Matematika). (vol. 2 no. 1, pp. 29-34, Maret 2016). http://jurnal.unsil.ac.id/index.php/ip3m/article/view/Eva21 Diakses pada 20 September 2018.

Peraturan Menteri Pendidikan Nasional Nomor 22 tahun 2006 tentang standar isi untuksatuan pendidikan dasar dan menengah bahwa Standar Kompetensi (SK) dan KompetensiDasar (KD) IImu Pengetahuan Sosial. https://awidyarso65.files.wordpress.com/2008/08/permendiknas-no-24-th-2006-ttgkurikulum-ips-sd.pdf. Diakses pada tanggal 14 Desember 2018.

Permana, Septian Aji. 2017. Strategi Pembelajaran IPS Kontemporer. Yogyakarta: Media Akademi.

Shoimin, Aris. 2017. 68 Model Pembelajaran INOVATIF dalam Kurikulum 2013. Yogyakarta: AR-RUZZ MEDIA

Sudjana, Nana. 2014. Penilaian Hasil Proses Belajar Mengajar. Bandung: Rosdakarya.

Undang-Undang Republik Indonesia No.20 Tahun 2003 tentang Sistem Pendidikan Nasional (SISDIKNAS). 